\title{
MAKNA SIMBOLIK UPACARA SIRAMAN PENGANTIN ADAT JAWA
}

\author{
Waryunah Irmawati \\ IAIN Surakarta \\ email: irmawatiwaryunah@yahoo.co.id
}

\begin{abstract}
Siraman (bathing) is a Javanese ritual ceremony that is done one day before the bride does the ijab qabul. In the siraman ritual, the operational rule and the equipments (uborampe) that are used are already definite (maton/pakem) as the symbols that have meanings. The meanings of the symbols in the siraman cannot be put off from Javanese context. Phenomenology and philosophy approaches using hermeneutic method towards siraman ritual are interpreted comprehensively to make the meanings of symbols clearly therefore the symbols in the siraman ritual can be understood. This research figures the inter relations among philosophy, culture and Islam.

$* * *$

Siraman (mandi) merupakan upacara adat Jawa yang dilakukan sehari sebelum pengantin melaksanakan ijab qabul. Dalam upacara siraman tata pelaksanaan dan peralatan (ubarambe) yang digunakan sudah maton/pakem sebagai sebuah simbol yang memiliki arti dan makna. Makna dan arti simbol dalam siraman tidak terlepas dari konteks Jawa. Model pendekatan fenomenologis, dan kemudian secara filosofis menggunakan metode hermeneutik diinterpretasikan secara komprehensif agar makin jelas arti dan makna sehingga akan lebih mudah memberikan pemahaman tentang saling hubungan (interelasi) antara filsafat, budaya dan Islam.
\end{abstract}

Keywords: interelasi, siraman, filsafat Jawa, budaya Jawa, Islam 


\section{A. Pendahuluan}

Salah satu isu pinggiran dalam studi agama dewasa ini adalah soal eksistensi transformasi dan relasi agama dan budaya lokal. Setiap etnis memiliki budaya yang berbeda satu dengan yang lainnya. Setiap budaya memiliki kekhasan yang sering disebut local culture, nilai-nilai yang dimiliki oleh local culture ini kemudian dapat menjadi bersifat local indigenious yang dijalankan oleh masyarakat. Hal ini juga berlaku bagi masyarakat etnis Jawayang memiliki budaya yang khas dan menjunjung tinggi sifat-sifat dan nilai-nilai luhur local indigenious dari kebudayaan yang dimilikinya.

Budaya Jawa merupakan salah satu kebudayaan lokal yang berpengaruh penting karena dimiliki sebagian etnis terbesar di Indonesia. Nilai-nilai Islam memiliki arti penting bagi budaya Jawa karena mayoritas masyarakat Jawa memeluk agama Islam. Dengan demikian hubungan nilai-nilai Islam dengan budaya Jawa menjadi menarik karena keberadaan Islam dan budaya Jawa yang cukup dominan pada bangsa Indonesia.

Hubungan antara Islam dan budaya Jawa dapat dikatakan sebagai dua sisi mata uang yang tidak dapat dipisahkan, yang secara bersama-sama menentukan nilai mata uang tersebut. Pada suatu sisi Islam yang datang dan berkembang di Jawa dipengaruhi oleh kultur atau budaya Jawa. Sementara disisi lain budaya Jawa makin diperkaya oleh khasanah Islam ${ }^{1}$. Dengan demikian, perpaduan antara keduanya menampakkan atau melahirkan ciri yang khas sebagai budaya yang sinkretis. Walaupun Islam tidak berusaha membentuk kebudayaan yang monolitik. Nyata bahwa di suatu daerah dengan daerah yang lain tidak selalu memiliki produk kebudayaan yang seragam, Islam telah memberikan peluang bagi pemeluknya untuk memelihara dan mengembangkan kebudayaan masing-masing.

Kehidupan masyarakat Jawa² sangat bersifat seremonial, mereka selalu ingin meresmikan suatu keadaan melalui upacara. Upacara-upacara yang

1 Dhanu Priyo Prabowo, Pengaruh Islam dalam Karya-karya R.Ng. Ranggawarsita, (Yogyakarta: Narasi, 2003), h. 9.

2 Lihat Moh Roqib, Harmoni Budaya Jawa( Yogyakarta: Pustaka Pelajar, 2007) h. 35. Yang dimaksud dengan masyarakate Jawa adalah mereka yang secara geografis bertempat tinggal di Jawa Tengah, Yogyakarta dan Jawa Timur dan Jawa Timur yang bukan menggunakan bahasa Madura meskipun masih kategori subkultur Jawa. 
dilakukan masyarakat Jawa berkaitan dengan siklus kehidupan manusia. ${ }^{3}$ Upacara-upacara ini dilakukan dalam rangka membereskan suatu keadaan untuk mencapai tujuan. ${ }^{4}$ Upacara-upacara ini termasuk adat istiadat yang sifatnya sakral baik mengenai niat, tujuan, bentuk upacara, perlengkapan upacara maupun tata laku pelaksanannya. ${ }^{5}$ Sehingga ketika akan melaksanakan upacara maka membutuhkan persiapan yang benar-benar matang bahkan terkesan jlimet.

Salah satu seremonial yang bersifat adat istiadat yang biasa dilakukan oleh masyarakat Jawa ketika akan menikahkan putra-putrinya adalah menyelenggarakan upacara siraman-nya itu disiram atau dimandikan. Siraman merupakan mandi ritual dimaksudkan agar calon pengantin menjadi bersih secara spiritual dan berhati suci. ${ }^{6}$ Di dalam upacara siraman ini memiliki tata urutan dan perlengkapan (ubarampe) yang sudah ada aturannya (maton/pakem). Nilai-nilai yang terkandung di dalam setiap rentetean alur pelaksanaan dan peralatannya semua menjadi penting karena memiliki arti dan makna.

Mempelajari dan memahami budaya Jawa ${ }^{7}$, ibarat memasuki hutan simbol yang rimbun, di dalamnya penuh tantangan, keunikan dan sekaligus daya tarik yang menggoda. Sadar atau tidak, banyak falsafah dalam budaya Jawa yang masih memiliki denyut aktualitas. Tidak semua falsafah Jawa usang, tetapi jika dilakukakan reaktualisasi akan semakin ada kejelasan makna. Hutan simbol rimbun yang penuh dengan isyarat semu, yang antik, yang artistik, yang memiliki nilai estetik dan nilai etik tidak akan dapat ditangkap arti dan maknanya apabila tidak diungkap secara komprehensif,

\footnotetext{
${ }^{3}$ Koentjaraningrat, Kebudayaan Jawa, (Jakarta: Balai Pustaka, 2000), h. 376.

${ }^{4}$ Nields Mulder, Kepribadian Jawa dan pembangunan Nasional, (Yogyakarta: Gadjah Mada University Press, 1986), h. 37.

${ }^{5}$ Harmanto Bratasiswara, Bauwarna: Adat Tata Cara Jawa, (Jakarta: Yayasan, 2000), h. 637

${ }^{6}$ Hariwijaya, Tata Cara Penyelenggaraan Perkawinan Adat Jawa, (Yogyakarta: Hanggar Kreator, 2004), h. 88.

${ }^{7}$ Lihat Astri S Susanto, Pengantar Sosiologi dan Perubahan Sosial, (Bandung: Bina Cipta, 1979), h.147 mengartikan budaya adalah hasil cipta, rasa dan karsa manusia dalam satu komunitas dalam rangka adaptasi diri individu dan kelompok agar tetap survive dan memiliki kualitas terbaik sesuai dengan pandangan hidup dan pengalamnnnya. Kebudayaan Jawa adalah kebudayaan yang berkembang dalam masyarakat Jawa dengan beberapa variasi dan heterogenitas masyarakat yang berkembang.
} 
bahkan bisa jadi menyebabkan pemahaman yang sepotong-potong atau hanya tertangkap kulitnya saja.

Banyak orang yang melihat dan melakukan adat upacara siraman ketika ada prosesi upacara perkawinan, tetapi banyak juga yang tidak tahu makna, arti dan tujuannya, padahal di dalamnya sarat dengan simbol yang perlu dipahami. Masing-masing simbol dalam alur rentetan pelaksanaan dan peralatannya penuh makna maka harus dilakukaan sebuah kajian agar makna dan simbol menjadi jelas arti, maksud dan tujuannya, sehingga upacara siraman tidak saja dijadikan lambang kemegahan bagi yang punya hajat dan status sosial dimana seseorang berada, ${ }^{8}$ tetapi upacara siraman diadakan dalam rangka melestarikan adat istiadat yang di dalamnya memang sarat dengan makna.

Adakalanya pertemuan antara budaya lokal dengan ajaran agama terlihat tidak sejalan dengan kaidah ajaran agama. Tetapi pengalaman sejarah yang panjang dalam hal integrasi budaya lokal dengan unsur budaya pendatang mampu menyajikan sebuah kekayaan budaya bangsa bahkan sebagai alat pemersatu bangsa, ${ }^{9}$ sebab budaya merupakan hasil karya manusia, sehingga manusia sendirilah yang dapat menerima, menolak atau mengubah budaya tersebut.

Salah satu bentuk integrasi budaya lokal dengan budaya pendatang adalah diadakannya upacara siraman ketika akan melakukan pernikahan. Upacara siraman yang di dalamnya memuat nilai-nilai filosofis dan nilai agama (religi), terlepas dari persoalan pro dan kontra, syirik atau tidak syirik, inilah sebuah kenyataan bahwa budaya siraman ini ada di masyarakat Jawa dan dijalankan oleh masyarakat Jawa. Dalam rangka mengungkap makna simbolis yang terdapat dalam upacara siraman yang penuh dengan simbolsimbol dan butuh pemaknaan ini, maka sebuah penelitian tentang upacara

8 Anisatun Muti'ah dkk, Penyerapan Nilai-nilai Budaya Lokal dalam Kehidupan Beragama di Cirebon dalamHarmonisasi Agama dan Budaya di Indonesia 1, (Jakarta: Balitbang Agama, 2009), h. 18 yang dikutip dari Leach. E. R, Political Syistem of Highland Burma: A Study of Kachin Sosial Structure (London: The Thlon Press, 1964), h. 10. Ritual atau upacara adalah setiap perilaku untuk mengungkapkan status pelakunya sebagai mahkluk social dalam structural di mana ia berada pada saat itu.

9 Siti Chamamah Suratno, "Agama dan Pluralitas Budaya Lokal: Dialektika Pemerkayaan Budaya Islam Nasional" dalam Zakiyuddin Baidhawy, Agama dan Pluralitas Budaya Lokal (Surakarta: Pusat Studi Budaya dan perubahan Sosial, 2002), h. 25. 
siraman penting dilakukan agar masyarakat yang melakukan upacara ini paham akan apa yang dilakukan.

\section{B. Simbol dalam Budaya Jawa}

Masyarakat Jawa atau yang sering disebut dengan orang Jawa memang memiliki budaya yang unik, budaya yang berbeda dengan budaya dari etnis yang lain. Keunikan tersebut salah satunya disebabkan karena masyarakat Jawa memiliki karakteristk budaya tersendiri yaitu: ${ }^{10}$

\section{Othak-athik Mathuk}

Tidak sedikit tentunya yang menyudutkan budaya Jawa dengan adanya budaya othak-athik mathuk ini. Dikatakan bahwa masyarakat Jawa terlalu mengada-ada, senangnya "othak-athik mathuk, othak-athik gathik, othakathik gathuk, tidak pernah berpikir kritis dan rasional, hanya mengandalkan rasa saja dan tidak logis. Padahal jika dirunut, jarang disadari bahwa "semua hal" (bahkan ilmu sekalipun) lahir atas OAM (othak athik mathuk) ini. Sedikit sekali yang mengakui bahwa munculnya teori sekaliber Archimides, Thomas Edison, Boyle dan yang lainnya sebenarnya berakar dari tradsisi OAM ini. Kita ingat ketika Thomas Edison menemukan "listrik". Ia melihat eksperimentasi ayam yang sedang mengerami telurnya. Setelah 21 telur itu menjadi panas, untuk kemudian keluarlah anak ayam. Ia buru-buru menuliskan eksperimentasinya tersebut, bahwa panas ada kaitannya dengan listrik. Yang sekarang ini tradisi tersebut digunakan oleh pengusaha telur dan petani ayam potong.

Belum lagi ketika Archimides menemukan "berat jenis" benda. Ia ketika itu bermain-main di air, mengangkat sebuah batu beberapa kali, ternyata terasa ringan dibanding batu itu jika diangkat di daratan. Kemudian Archimides pulang dan merumuskan temuannya. Jelas ini merupakan embrio AOM menjadi terbentuknya janin keilmuan.

Dalam filsafat Jawa tradisi OAM juga terdapat dalam tulisan Ha-na-ca-raka: Ha-na itu nyata ada, mengisyaratkan ilmu kasunyatan. Ca-ra-ka, mengandung aksara yang menyiratkan kata cipta, rasa dan karsa, yakni salah satu unsur kelengkapan hidup manusia. $D a-t a-s a-w a-l a$ : mengiaskan zat yang

${ }^{10}$ Suwardi Endraswara, Falsafah Hidup Jawa, (Yogyakarta: Cakrawala, 2006), h. 19-27. 
da-ta-sa-wa-la, yakni zat yang tidak pernah dapat salah, yaitu Tuhan. Pa-dhaja-ya-nya: "sama jayanya". Sedang Ma-ga-ba-tha-nga: Ma menyiratkan kata sukma, dan ga menyiratkan kata angga (badan). Maksudnya jika sukma masih bersatu dengan badan, manusia itu masih hidup, tetapi jika sukma telah meninggalkan badan, manusia itu mati, tinggal ba-tha-nga yaitu bangkainya. Sukma kembali kepada Tuhan.

Kecerdasan nalar dan rasa ternyata memberikan sumbangan penting dalam menumbuhkembangkan budaya Jawa. Akhirnya tradisi OAM semakin digemari dan dijadikan sandaran analisis kultural dalam segala hal. Orang Jawa asli maupun yang telah terkena pengaruh budaya lainpun sedikit banyak dinyatakan selalu menggunakan pisau analisa OAM. Pisau analisis ini disamping mampu menyelesaikan hal ihwal kultural yang pelik juga lebih mewakili ranah spiritual Jawa.

Jika ditelusuri lebih lanjut OAM berakar dari pengertian luas kerata basa. Oleh karena ada yang mengartikan kerata basa berasal dari kata kerata artinya negesi tembung manut pepindaning wandane (memberi makna kata berdasarkan atas bunyi suku katanya). Model demikian tidak lain jarwa dhosok (memaksakan kata dengan mendesak-desakkan) memaksakan, bahkan sekedar "mempermainkan" kata, utamanya "bunyi". Cara semacam ini memang terkesan spekulatif, namun tetap berdalih dan logis.

Kerata basa dalam istilah folklore Jawa lebih dikenal dengan nama etimologi rakyat. Etimologi rakyat adalah cara penjelasan kata yang unik, bahkan kadang-kadang dianggap kurang pas dan kurang relevan. Etimologi rakyat tetap masuk akal, hanya saja memang dianggap kurang tepat khususnya bagi rakyat yang masih terbelakang.

\section{Orang Jawa Senang Simbol}

Penampilan orang Jawa penuh dengan isyarat atau sasmita.banyak hal yang terselubung, diungkapkan dalam tanda-tanda yang khas. Seperti halnya kalau ada perawan Jawa yang akan dijodohkan dengan laki-laki, perawan tersebut tidak perlu mengatakan mau atau sebaliknya menolak. Ia cukup dengan menggerakkan mimik atau gerakan tangan dan angukan saja andaikata mau. Bahkan kalau perempuan terus terang mau, dianggap kurang tepat (pener) meskipun sebenarnya bagus (bener). 
Sifat orang Jawa yang demikian itu biasanya muncul dalam usaha mendidik atau menyampaiakan gagasan-gagasan kepada orang lain tidak "terus terang', melainkan menggunakan simbol atau lambang budaya. Kenyataan ini dipengaruhi oleh sikap hidup orang Jawa yang lebih suka mengatakan sesuatu secara tidak langsung hingga sukar diketahui seketika apa sesungguhnya yang dimaksud atau dikehendaki.

Budaya semu penuh dengan simbol. Di dalamnya banyak menampilkan ungkapan. Simbol dan ungkapan tersebut sebagai manifestasi pikiran, kehendak dan rasa Jawa yang halus. Segala sikap dan tingkah laku terbungkus dengan semu diupayakan agar mengenakkan sesame hidup. Dalam arti melalui hal-hal yang tersamar, ada yang disembunyikan tetapi tetap jelas. Karena masing-masing pihak pemakai simbol telah paham. Adapun yang belum paham diharapkan untuk mempelajari dan menyelami kedalaman simbol tersebut.

\section{Prinsip Cocog atau Ngelmu Titen}

Karakteristik orang Jawa yang tidak kalah penting dan menarik adalah kegemarannya memanfaatkan prinsip cocog. Cocog artinya tepat sesuai dengan keadaan. Prinsip cocog bisa dianggap buah pola pikir Jawa yang berdasarkan pada ilmu titen artinya ilmu yang berlandaskan pada kebiasaan yang berulang-ulang, dicatat, direnungkan dan diamalkan. Orang Jawa banyak berpegang teguh pada prinsip cocog ini sebagai arah hidupnya. Kompas hidup yang dibangun menggunakan pengalaman nyata. Pengalaman itulah yang dinamakan prinsip cocog dan sarat ngelmu titen.

Buah prinsip cocog atau ilmu titen biasanya diwujudkan ke dalam bentuk primbon. Sampai sekarang ada berpuluh-puluh primbon yang dihasilkan orang Jawa. Primbon tersebut ada yang disimpan baik-baik dan selalu dibuka ketika orang Jawa akan menjalani apa saja. Primbon tersebut menjadi "kitab kecil" yang menjadi pedoman tingkah laku hidup orang Jawa. Dengan primbon tersebut orang Jawa membudayakan prinsip cocog dan ilmu titen baik secara real maupun simbolik.

Penerapan prinsip cocog dan ngelmu titen juga disertai laku, karenanya orang Jawa sering menjalankan nglakoni pada saat menggunakan prinsip dan 
ngelmu tersebut. Peristiwa nglakoni dapat berupa semedi, bertapa, mencegah hawa nafsu (puasa). Melalui laku batin orang Jawa akan mendapatkan wisik, wahyu dan pulung.

\section{Siraman dalam Pandangan Filsafat dan Agama}

Dalam upacara siraman baik dari sisi tata urutan pelaksanaan maupun dari sisi ubarampe yang digunakan dalam upacara tersebut memiliki makna, walaupun hanya diungkapkan melalui simbol-simbol:

\section{Pengertian Siraman}

Siraman, dari kata siram yang artinya menguyur atau mandi. Banyak sekali ritual mandi yang dilakukan oleh masyarakat Jawa, terutama ketika akan melakukan sebuah upacara budaya. Sepasang pengantin akan melangsungkan ijab qabul sehari sebelumnya juga melakukan upacara siraman. Mandi dalam kehidupan sehari-hari dilakukan agar orang menjadi bersih badannya, segala kotoran yang melekat di badan akan hilang tersapu air dan sabun. Akan tetapi hakikat dari mandi (siraman) dalam upacara pengantin adat Jawa tidak hanya sekedar membersihkan wadag badan tetapi juga membersihkan jiwa. Membersihkan diri dari noda dan dosa serta sifat-sifat yang kurang baik. Membersihkan segala gangguan agar supaya pada saat prosesi ijab qabul tidak lagi ada aral yang melintang. Pengantin agar dapat memulai hidup baru dengan keadaan yang bersih dan suci.

Filsafat Jawa adalah ngudi kawicaksanan dengan mengetahui awal dan akhir kehidupan sehingga akan mencapai tujuan sangkan paraning dumadi. Untuk sampai sangkan paraning dumadi maka manusia wajib melakukan penyucian dan pembersihan.Bersih yang dimaksud adalah bersih dari segala dosa artinya harus melakukan piwulang-piwulang keutamaan dengan tidak lupa pada Tuhan.

Secara rasional siraman (mandi) mempunyai pengaruh secara fisik, badan yang loyo akan menjadi segar apabila terkena siraman air, indera penciuman akan terpuaskan dengan wanginya bunga-bunga sritaman, indera peraba dapat menikmati segarnya air yang menyapu tubuh, indera penglihatan menjadi bahagia melihat air yang diberi berbagai macam bunga, 
biasanya dengan diiringi musik gamelan maka gelombang otakpun menjadi lebih tenang.

Islam tidak mengenal istilah siraman, tetapi istilah mandi (ghusl) ada dalam ajaran Islam. Mandi (ghusl), menurutsyara, ialah meratakan air pada seluruh badan untuk țaharah dari hadas besar.

Mandi dalam konteks Islam dan siraman dalam pandangan filsafat memiliki relasi yang sangat sinergis kedua-duanya memiliki makna bahwa baik mandi maupun siraman berusaha menghilangkan kotoran, dalam Islam disebut hadas sedangkan dalam pemaknaan filsafat disebut kotor/dosa. Tujuan dari keduanya sama yaitu untuk mencapai kesucian, dalam Islam agar syah untuk melakukan ibadah shalat, puasa dan haji, sedangkan untuk filsafat agar suci untuk dapat sangkan paraning dumadi.

\section{Pelaksanaan Upacara Siraman}

Upacara siraman dilakukan antara pukul 10.00 - 15.00 sehari sebelum upacara panggih. Konon para bidadari turun mandi bersama bersuka ria kirakira pukul 11.00 pagi. Agar dapat secantik dan seceria bidadari, maka calon pengantin mandi pukul 11 siang. Namun, ada pula calon pengantin yang mandi sekitar pukul 15.00 demi kepraktisan.

Pengantin diibaratkan sebagai seorang yang cantik menawan, sehingga untuk mandi saja waktunya disamakan dengan bidadari. Makna visual bidadari itu adalah wanita suci yang menyenangkan dipandang mata, menyejukkan dilihatnya, menentramkan hati setiap memandangnya. Rupanya cantik jelita, kulitnya mulus, memiliki akhlak yang mulia.

Dalam pemikiran orang Islam, bidadari adalah penghuni surga yang merupakan hadiah bagi wanita shalehah, istri shalehah. Laki-laki yang mati syahid dijanjikan mendapatkan bidadari di surga. ${ }^{11}$ Sebuah visualisasi bahwa bidadari adalah sesuatu yang diinginkan. Sesuatu yang diinginkan oleh manusia dalam pemikiran filsafat disebut sesuatu yang memiliki nilai, memiliki guna dan memiliki manfaat, sehingga dikejar oleh manusia.

\footnotetext{
${ }^{11}$ Joko Syakban, Misteri Bidadari Surga, (Bandung: Mizan Publika, 2009), h. xxv.
} 
Waktu antara pukul 10.00 - 15.00 adalah waktu setiap hari dimana pengaruh matahari paling besar.Mandi di udara terbuka diharapkan dapat menyerap energi matahari, semangat dan stamina untuk mempersiapkan diri dalam menghadapi prosesi ritual pernikahan yang panjang.

Sekarang demi kepraktisan dan efisiensi waktu yang biasa dipakai untuk melakukan siraman adalah pukul 15.00. Dengan demikian calon pengantin putri tidak perlu terlalu lama menunggu di dalam kamar. Selain itu, para perias bersama petugas pendukung (kameraman, fotografer, pranata adicara) juga tidak banyak membuang waktu. Upacara dilangsungkan secara terus menerus (banyu mili). Dengan demikian, pemangku hajat juga menghemat biaya mewakili nilai ekonomi sebab waktu tidak banyak yang terbuang, dari ongkos kameramen, pranata adicara karena kerjanya hanya setengah hari maka diasumsikan lebih murah, dengan bayu mili, terus menerus sehingga hajatan cepat selesai.

\section{Tujuan Siraman}

Tujuan diadakannya siraman dalam rangka memohon berkah dan rahmat Tuhan Yang Maha Esa agar calon pengantin dibersihkan dari segala godaan dan pengaruh buruk, sehingga dapat melaksanakan upacara hingga selesai dengan lancar dan selamat. Selain itu, calon pengantin juga selamat dalam membangun rumah tangga dan dapat mencapai tujuan pekawinan. Hal ini sesuai dengan filsafat Jawa yang berdasarkan pada tiga aras yaitu aras dasar ber-Tuhan, aras kesadaran semesta dan aras keberadaban manusia. Aras dasar ber-Tuhan menyatakan adanya Tuhan yang Murbeng Dumadi (Penguasa Alam Semesta). Di dalam siraman pun aras filosofi dasar ber Tuhan ini muncul yaitu bahwa Tuhan sebagai tempat memohon berkah, segala sesuatu berasal dari-Nya sehingga konsep permohonan inipun dilakukan. Tuhan sebagai tempat seluruh permintaan manusia terutama berkah keselamatan dan kelancaran dalam kehidupan.

Konsep monoteisme jelas terlihat, bahwa yang dipercaya sebagai tempat meminta adalah satu yaitu Tuhan, tidak ada hal lain yang dapat dijadikan sebagai tempat meminta, sesaji yang digunakan hanyalah sebagai sarana untuk sampai kepada-Nya. Konsep monoteisme yang hanya mengakui satu tuhan sebagai tempat meminta dan memohon ini sama dengan ajaran Islam 
"Ashhadu anlā ilāha illallāh" Tiada Tuhan selain Allah. Segala sesuatu yang akan kita lakukan apalagi itu urusan keberlangsungan hidup manusia, maka harus selalu ingat pada yang di atas (maksudnya Tuhan), sebab apapun yang terjadi di dunia ini dan pada manusia ini hanya Tuhan yang mengaturnya, sehingga permohonan kepada Tuhan agar selamat dan sentaosa penting dilakukan. Menyucikan diri agar pelaksanaan upacara perkawinan lebih khidmat dan selamat, karena keesokan harinya akan melaksanakan upacara pernikahan yang sakral dan agung.

Selain untuk mendapatkan rahmat dan berkah dari Tuhan maka upacara siraman dilakukan dalam rangka membersihkan segala "kotoran /rereged" hingga bersih (resik) seutuhnya, resik jiwa dan resik raga. Ini sebagai simbolik bahwa pengantin bertekad untuk berperilaku bersih, baik dalam bertutur kata maupun bertindak. Bersih dalam pikir (cipta), bersih dalam hati (rasa), bersih dalam bertindak (karsa). Aras kedua dan ketiga Filsafat Jawa bahwa manusia harus dapat hidup dengan sesama dan selaras dengan alam muncul juga dalam tujuan siraman ini. Manusia bersih adalah manusia yang berperilaku baik dan benar, perilaku pada dasarnya digunakan untuk kehidupan bersama sebagai mahkluk sosial.

Di samping itu juga siraman atau mandi dimaksudkan untuk menyegarkan badan, selain segar secara fisik, juga mengandung harapan segar secara psikologis, artinya menyiapkan dan menyegarkan jiwa untuk melangkah pada kehidupan yang baru. Harus ada proses penyelarasan diri, masing-masing berusaha untuk menyesuaikan dengan pasangannya.

\section{Sungkeman}

Sebelum melakukan siraman maka calon pengantin harus melakukan sungkeman yangsecara arti nominal adalah kedua mempelai berlutut atau jongkok didepan orang tuanya, menyembah untuk minta doa restu. Sedangkan makna simbolik yaitu tanda bakti anak kepada orang tua yang telah membesarkannya hingga dewasa, permohonan anak kepada orang tua supaya diampuni kesalahannya dan memohon doa restu supaya dalam membina bahtera rumah tangga dapat bahagia dan sejahtera. Pengantin pria melepaskan keris yang merupakan lambang kekuatan yang dipakainya ketika sungkeman, hal ini mempunyai makna simbolik penghormatan kepada orang 
tua., serta sebesar apapun pangkat atau kekuatan yang dimiliki oleh anak, maka di hadapan orangtuanya tidak boleh ditampakkan.

Etika Jawa sangat memberikan penghormatan kepada yang lebih tua, baik dari segi tutur kata maupun dari segi tingkah laku. Jongkok sebagai pengejawantahan dari yang muda harus hormat dan tunduk kepada yang tua. Doa pangestu dari orangtua selalu diharapkan oleh si anak dalam rangka melangsungkan pernikahan. Dalam konsep Islam restu Allah adalah restu kedua orang tua.

\section{Pelaksana Siraman}

Pelaku siraman selain orangtua sendiri, adalah para sesepuh atau anggota keluarga yang dianggap pantas dan dipilih sebab mengandung maksud dan tujuan. Dipilih sesepuh yang jangkep (masih bersuami istri, bukan duda atau janda) jika terpaksa harus dilakukan duda dan janda maka duda dan janda yang cerai karena meninggal maksud dan tujuannya agar sepasang pengantin ini panjang umur perkawinannya tidak akan berpisah di tengah jalan, sampai kaken ninen (kakek nenek). Perceraian merupakan perbuatan yang memalukan sebab masing-masing pasangan berarti tidak dapat menyelaraskan hidup dengan pasangannya, tidak dapat nrimo ing pandum, menerima segala kelebihan dan kekurangannya. Dalam Islam perceraian diperbolehkan akan tetapi merupakan perbuatan yang dibenci oleh Allah.

Selain itu ada sesepuh yang dipilih adalah keluarga atau orang-orang yang sukses dalam hidupnya, misalnya sukses karier, sukses mendidik anak, bahagia dalam keluarga. Harapannya adalah agar keberhasilan atau kesuksesan para sesepuh yang memberikan siraman dapat diikuti jejaknya oleh para calon pengantin. Kebahagiaan dunia dalam bentuk sukses dalam karier maupunsukses dalam mendidik anak merupakan harapan bagi semua orang termasuk manusia Jawa, sebab kebahagiaan dunia ini akan dipakai untuk mencari kebahagiaan akhirat.

Pelaku siraman berjumlah ganjil misalnya 5, 7, 9, 11 atau 13.Umumnya

pelaku siraman yang paling dipilih adalah 7. Konon Tuhan yang Maha Esa menyukai bilangan ganjil. Tujuh (pitu) bermakna pitulungan (pertolongan). 
Ini menggandung harapan (1) calon pengantin dalam hidupnya nanti senantiasa mendapatkan pertolongan dari Tuhan dan sesama (2) calon pengantin senantiasa memberikan bantuan kepada orang lain. Mengandung piwulang kautaman ada konsep saling memberi dan menerima pitulungan, melakukan siraman tidak saja harapan bagi yang melakukan tetapi harapan semua orang sebab nantinya pengantin dapat juga memberi pitungan kepada orang lain selain juga mendapatkan pengantin mendapatkan pitumgan dari Tuhan.

Angka pitu yang kemudian menjadi pitulungan merupakan proses othak athik mathuk, proses ini sangat lumprah/ kebiasaan yang ada di budaya Jawa. Angka 7 inipun juga nanti akan muncul ketika siraman dilakukan dengan mencampurkan bermacam-macam air yang berjumlah 7 macam yang berasal dari 7 sumber mata air. Betapa pentingnya pitulungan bagi orang Jawa.

\section{Ubarampe Siraman dalam Pandangan Filsafat dan Islam}

Dalam siraman terdapat peralatan (piranti/ubarampe) yang harus dipersiapkan. Piranti tersebut tidak asal piranti akan tetapi semua yang dipakai mengandung makna.

Piranti pertama adalah berupa sesaji atau hardware dalam bentuk makanan yang berisi tumpeng robyong, jajan pasar, pisang raja, jenang abang putih, boro-boro, palang, empluk kecil-kecil disisi beras, telur dan bumbu dapur, ayam kampung, satu butir kelapa yang sudah dikupas. Juplak diisi minyak kepala, kembang telon, gula Jawa tangkep.

Othak athik mathuk dari tumpeng adalah 'metu dalan kang lempeng', manusia dalam kehidupannya senantiasa memperhatikan tata laku yang lurus, menjalankankan perintah-Nya dan menjauhi larangan-Nya, dalam Islam disebut sebagai hanaîf, sebagai aplikaksi dari "ihdina 'ș-șirāța 'lmustaqim".

Tumpeng robyong sebagai lambang kesuburan dan kesejahteraan, tumpeng robyong ini bentuknya semakin estetis karena terdiri dari aneka hiasan dari lombok merah, brambang. Bawang dan ada hiasan sayur sayurannya sehingga terlihat indah.

Jajan pasar adalah simbol pengingat akan kehidupan dunia yang seperti saat ini. Sebagai manusia, kita seakan diingatkan agar mampu melihat 
kenyataan dunia dan tidak mudah larut sehingga penting bagi kita selalu ingat pada kehidupan akhirat. Jajan pasar ini juga sebagai lambang sesrawungan (hubungan kemanusiaan, silaturahmi). Pasar dianggap sebagai tempat selain untuk praktek ekonomi juga untuk tempat bertemunya banyak orang.

Pisang raja dimaksudkan agar mempelai memiliki sifat seperti raja yang ambeg adil paramarta berbudi bawa leksono, menjadi orang adil, berbudi luhur dan menepati janji. Hal ini merupakan pelajaran etika kehidupan, agar pengantin memiliki watak seperti pisang yang dapat hidup dimana saja (ajur ajer). Selalu dapat menyesuaikan diri dengan lingkungannya. Semua bagian dari pisang dapat dimanfaatkan oleh manusia. Buahnya dapat dinikmati oleh manusia dengan kandungan gizi dan vitamin yang cukup. Daunnya dapat dipakai sebagi pembungkus makanan, sementara pada zaman dulu daun pisang ini oleh orang desa dipakai sebagai pelindung ketika hujan. Gedebok pisang dapat dipakai sebagi pupuk dan keranjang tembakau. Bonggolnya pun dipakai ketika orang Jawa mengadakan perhelatan sebagai tungku membuat jenang /dodol.

Piranti yang kedua adalah air siraman: toya pamorsihatau disebut juga banyu perwitosari. Perwita berarti suci, sari berarti bunga, yakni air yang ditabur bunga sritaman (mawar, melati dan kenanga). Asal air dapat memilih salah satu dari (1) 7 sumber dari berbagai tempat (2) air dari keraton (3) air tempuran (pertemuan dua hilir sungai) (4) berbagai sendang atau sumber tua, sumur sumur tua yang air nya tidak pernah surut /kering. Untuk yang beragama Islam biasanya memasukkan air Zam-Zam sebagai salah satu dari 7 mata air tersebut.12

Air berjumlah tujuh melambangkan harapan hidup yang dapat saling menolong (mitulungi, pitulungan). Air keraton yang diharapkan dapat memberikan manfaat bagi rakyat atas kewibawaan dan kemakmuran raja (sawab). Air tempuran melambangkan pertemuan dua insan (calon pengantin pria dan wanita). Air sumber tua yang tidak pernah kering melambangkan hidup calon penganten dapat memberikan penghidupan seperti layaknya air yang tidak pernah kering, rezeki terus mengalir, kemuliaan terus

12 Wawancara dengan Ki Harsono, Pranata Adicoro dan Dalang di Ambarawa, tanggal 7 Agustus 2010. 
didapat, dan yang tua dapat memberikan pengayoman kepada yang lebih muda.

Dalam mistik Jawa air yang mengalir merupakan simbol dari kehidupan sebab air akan menjadikan tanah menajdi subur, sehingga mayarakat menjadi sejahtera. Dalam pemikiran filsafat seperti yang diungkapkan oleh filsuf Yunani Kuno bahwa asal mula segala sesuatu adalah air. Air yang yang memberikan kehidupan tetapi sekaligus juga dapat mematikan, air sangat dibutuhkan oleh manusia akan tetapi jika terlalu banyak air (banjir) maka akan menjadi bencana mematikan.

Piranti ketiga adalah bunga sritaman (mawar, melati dan kenanga) secara simbolik melambangkan keharuman. Secara fisik keharuman bunga tersebut dapat meresap ke tubuh calon pengantin. Secara simbolik bunga sritaman calon pengantin diharapkan memliki keharuman nama, dapat dicontoh oleh sesama seperti pepatah: "Gajah mati meningalkan gading, harimau mati meninggalkan belang, manusia mati meninggalkan nama."

Bunga memiliki makna filosofis bagi orang Jawa agar kita dan keluarga senantiasa mendapatkan "keharuman". Keharuman merupakan kiasan dari berkah-syafa'at yang berlimpah dari para leluhur, dapat mengalir (sumrambah) kepada anak turunnya. Masing-masing aroma bunga, dapat menjadi ciri khas masing-masing leluhur. Desa mawa cara, negara mawa tata. Beda daerah, beda masyarakatnya, beda leluhurnya, beda pula tradisi dan tata cara penghormatannya. Bahkan aroma khas bunga serta berbagai jenis dedaunan tertentu sering menjadi penanda bau khas salah satu leluhur kita. Bila bau harum bunga tiba-tiba hadir di sekitar anda, kemungkinan besar ada salah satu leluhur anda yang hadir di dekat anda berada.

Kembang melati, rasa melad saka jero ati.dalam berucap dan berbicara hendaknya kita selalu mengandung ketulusan dari hati nurani yang paling dalam. Lahir dan batin haruslah selalu sama, kompak, tidak munafik. Menjalani segala sesuatu tidak asal bunyi, tidak asal-asalan. Kembang melati, atau mlathi, bermakna filosofis bahwa setiap orang melakukan segala kebaikan hendaklah melibatkan hati (sembah kalbu), jangan hanya dilakukan secara gerak ragawi saja.

Kembang kenanga, keneng-e atau gapailah..! segala keluhuran yang telah dicapai oleh para pendahulu. Berarti generasi penerus seyogyanya mencontoh perilaku yang baik dan prestasi tinggi yang berhasil dicapai para 
leluhur semasa hidupnya. Kenanga, kenang-en ing angga. Bermakna filosofis agar supaya anak turun selalu mengenang, semua "pusaka" warisan leluhur berupa benda-benda seni, tradisi, kesenian, kebudayaan, filsafat, dan ilmu spiritual yang banyak mengandung nilai-nilai kearifan lokal (local wisdom).

Kembang mawar-mawi arsa-dengan kehendak atau niat. Menghayati nilai-nilai luhur hendaknya dengan niat. Mawar, atau awar-awar ben tawar. Buatlah hati menjadi "tawar" alias tulus.Jadi niat tersebut harus berdasarkan ketulusan, menjalani segala sesuatu tanpa pamrih (tapa ngrame) sekalipun pamrih mengharap-harap pahala. Pahala tetap saja "upah" yang diharapkan datang dari Tuhan apabila seseorang melakukan suatu perbuatan baik. Pamrih pahala ini tetap saja pamrih, berarti "belum mencapai ketulusan yang tiada batas" atau keadaan rasa tulus pada titik nihil, yakni duwe rasa, ora duwe rasa duwe (punya rasa tidak punya rasa punya) sebagaimana ketulusan tuhan/kekuatan alam semesta dalam melimpahkan anugerah kepada seluruh makhluk. Pastilah tanpa pamrih.

Piranti keempat berupa alas duduk (a) kloso blangko (klasa/tikar pandan dengan anyaman besar) ${ }^{13}$ (b) godhong (dedaunan): apa-apa, kluwih, alang-alang, kara dhadha serep, eri kemarung, maja, dlingo belengkle dibungkus mori putih (c) kain tutup letrek jingo, bangun tlak sindhur liwatan, sembagi, yuyu sakandhang, sekar mayang, lurih pulowatu. Klasa blangko melambangkan harapan bahwa calon pengantin kelak dapat hidup bersahaja, walaupun bergelimang kemewahan, tidak berfoya-foya. Daun apa-apa melambangkan harapan agar perhelatan tidak aral melintang suatu apapun. Alang-alang melambangkan harapan agar perhelatan tidak ada halangan apapun atau ora ono opo-opo "tidak ada halangan apa-apa". Daun kara melambangkan harapan segala sikara (cobaan) atau sukreta (siksaan, rintangan, sakit) harus dihadapi dengan tegar dan dihilangkan. Hidup ini tidak akan lepas dari cobaan (sikara). Daun kluwih melambangkan harapan calon pengantin diberi kelebihan prestasi, sosial ekonomi, pangkat, jabatan, karier, kewibawaan, dsb. Daun dhadhap serep melambangkang harapan kehidupan calon pengantin penuh dengan ketrenteraman adhem ayem (konon daun dhadhap serep dapat menurunkan panas). Duri kemarung, maja dan dlingo

13 Kuswo Endah, "Petung, Prosesi dalam Ritual Manten Masyarakat Jawa” dalam Jurnal Kebudayaan Jawa (Yogyakarta: Jurusan Pendidikan Bahasa Daerah Fakultas Bahasa dan Seni UNY, Vol. I No. 2 Agustus 2006), h. 147. 
bengkle sebagai penolak bala agar kehidupan calon pengantin dijauhkan dari mara bahaya. Mori putih melambangkan kesucian dan kepasrahan kepada Tuhan.

Piranti kelima; dua kelapa hijau (cengkir) yang diikat sabutnya melambangkan calon pengantin senantiasa berdua, seia sekata, terikat tali kasih dan sayang hingga akhir hayat, juga melambangkan kedua calon besan bersatu tekad untuk menikahkan puta-putrinya.

Cengkir alias kelapa muda diterjemahkan sebagai kencenging pikir atau tekad yang keras. Selain itu cengkir merupakan simbol dari kandungan tempat jabang bayi atau lambang keturunan. Tebu diartikan sebagai antebing kalbu. Tebu yang rasanya manis adalah suatu pengharapan agar dalam kehidupannya pasangan pengantin ini selalu merasakan yang manis-manis, kegembiraan, terjauhkan dari kesusahan. Tebu juga dimaksudkan sebagai lambang hidup manusia, kesuksesan hidup manusia harus dibangun dengan akar yang kuat (akar tebu), melalui rintangan dan pengalaman hidup (ruas tebu), sampai terjadinya kesuksesan (tebu yang menjulang tinggi).

Perhatikan proses tumbuhnya tebu. Ketika ditanam, mata tunas yang menempel pada ruas tebu secara perlahan namun pasti menjelma sebagai tanaman tebu baru. Tebu muda ini terus tumbuh menjulang tinggi ke angkasa. Pada waktunya, tebu akan merunduk ke bumi. Proses tumbuhnya tebu baru ini sama persis dengan alur kehidupan manusia. Di saat masih muda belia, manusia akan berlomba-lomba menggapai cita-citanya. Seiring dengan bertambahnya usia, manusia akan mengalami masa kematangan emosional. Sebagai mahluk yang sempurna, manusia sebaiknya harus bisa mawas diri. Melihat ke bawah jauh lebih bijaksana dalam menjalani hidup dan kehidupan. Di lihat dari segi rasanya, tebu adalah salah satu tanaman yang banyak disukai mahluk hidup karena rasanya yang manis. Dari rasa tebu yang manis ini, keberadaan manusia di muka bumi ini hendaknya bisa mendatangkan manfaat bagi sesama mahluk hidup. Makna hidup yang terkandung dalam tebu ini sama persis dengan bambu. Bentuknya yang beruas-ruas serta panjang melambangkan panjang umur. Sementara warnanya yang hijau bermakna kemurahan rejeki.

Pisang raja yang ayu disimbolkan sebagai harapan akan kehidupan yang tata tentrem kerta rahayu, kehidupan yang indah, bahagia, tentram dan sejahtera. Makna dipilihnya pisang yang sudah masak adalah agar pasangan 
yang akan menikah telah memiliki pemikiran dewasa atau telah masak. Sedangkan pisang raja mempunyai makna pengharapan agar pasangan yang akan dinikahkan kelak mempunyai kemakmuran dan kemuliaan seperti raja.

Piranti keenam, konyoh mancawarna lulur terbuat dari tepung beras dan kencur serta bahan pewarna (a) tepung konyoh lima warna (b) ron kemuning (c) mangir. Konyoh lima warna melambangkan kemanunggalan warna cahaya (pamor) sarana pambukaning pamor "sarana pembuka aura" agar segala unsur cahaya berkumpul dan membuahkan cahaya pamor sehingga calon pengantin tampak lebih cantik (wanita) atau tampan (pria). Secara simbolik konyoh manca warna lulur bermakna agar segala cahaya menyatu di tubuh calon pengantin sehingga calon pengantin tampak berwibawa dan indah untuk dipandang.

Piranti ketujuh, sehelai kain motif batik grompol yang dipakai oleh ibu pengantin perempuan. Filosofi batik grompol, berarti berkumpul atau bersatu, dengan memakai kain batik grompol ini diharapkan berkumpulnya segala sesuatu yang baik seperti rezeki, keturunan, dan kebagaiaan hidup dan motif nagasari atau motif lain, seperti sidoluhur, sidomukti, semenrama, sidoasih, dsb.

Hubungan antara Islam dan budaya Jawa atau sebaliknya dikatakan sebagai dua sisi mata uang yang tidak dapat terpisahkan yang secara bersama-sama menentukan nilai mata uang tersebut. Pada satu sisi Islam datang dan berkembang di Jawa dipengaruhi oleh kultur dan budaya Jawa. Sementara itu pada sisi yang lain, budaya Jawa makin diperkaya oleh khasanah Islam. Dengan demikian, perpaduan antara keduanya menampakkan ciri yang khas sebagai budaya yang sinkretis. Pada titik inilah terjadi semacam "simbiosis mutualisme" antara Islam dan budaya Jawa. Keduanya dapat berkembang dan diterima oleh masyarakat Jawa tanpa menimbulkan friksi dan ketegangan. Padahal antara keduanya sesungguhnya terdapat beberapa celah yang sangat memungkinkan untuk saling berkonfrontasi.

\section{E. Kesimpulan}

Siklus kehidupan yang mencakup kelahiran, pernikahan dan kematian merupakan momentum yang sangat penting, baik bagi yang mengalami, keluarga, maupun orang di sekelilingnya, termasuk masyarakat Jawa sebagai sebuah etnis yang memiliki ritual-ritual siklus kehidupan tersebut dalam hal 
ini adalah siraman yang dilakukan calon pengantin sehari sebelum hari ijab dan qabul.

Siraman sebagai upacara adat yang dilakukan memiliki alur rangkaian acara yang pakem "sudah mapan" sehingga susunan acaranyapun sudah mapan. Diawali dari adanya sungkeman atau pangakbeten calon pengantin kepada kedua orangtuanya sampai tata cara siapa urut-urutan siapa yang memandikan, sebab semuanya memiliki makna dan simbol.

Sama seperti halnya upacara-upacara adat yang lain, siraman inipun juga membutuhkan berbagai ubarampe, yang masing-masing ubarampe memiliki makna. Jika disimpulkan semua ubarampe memberikan makna yang sesuai dengan asas dasar falsafah Jawa yaitu asas dasar ber-Ketuhanan, aras dasar dengan semesta dan aras dasar keberadaan manusia, bahwa manusia Jawa selalu ingat akan Tuhan sebagai tempat untuk memohon, adanya keinginan untuk selalu hidup bersama dengan manusia yang lain dengan budi pekerti yang baik dan hidup selaras dengan alam semesta.

Pertemuan antara filsafat sebagai pandangan hidup manusia Jawa dengan budaya dan Islam sebagai agama mayoritas yang di anut oleh masyarakat Jawa, memberikan warna tersendiri. Dengan menggunakan pemahaman secara filsafat dan pandangan Islam terhadap katakteristik budaya Jawa maka ketiga saling memiliki hubungan antara satu dengan yang lainnya. Termasuk di dalam budaya siraman terdapat saling hubungan antara nilainilai filasafat Jawa dengan ajaran-ajaran Islam, terlepas dari persoalan syirik dan tidak syirik. $[\mathrm{w}]$ 


\section{BIBLIOGRAFI}

Ahnadi, Asmoro, FilsafatUmum, Jakarta: Raja Grafindo Persada, 1995.

Astiyanto, Heniy, Filsafat Jawa, Menggali Butir-butir Kearifan Lokal, Yogyakarta: Warta Pustaka, 2006.

Bodgan, R. \& Taylor, S.J., Kualitatif Dasar-dasar Penelitian, Surabaya: Usaha Nasional, 1993.

Bratasiswara, Harmanto, Bauwarna: Adat Tata Cara Jawa, Jakarta: Yayasan Citra, 2000.

Budaya, Surakarta: UNS Press, 1996.

Ciptoprawiro, Abdullah, FilsafatJawa, Jakarta: Balai Pustaka, 1996.

Dibyasuharda, Dimensi Metafisik dalam Simbol: Ontologi Mengenai Akar Simbol, Yogyakarta: UGM Press, 1990.

Endah, Kuswo, "Petung, Prosesi dalam Ritual Manten Masyarakat Jawa", Jurnal Kebudayaan Jawa, Yogyakarta: Jurusan Pendidikan Bahasa Daerah Fakultas Bahasa dan Seni UNY, Vol. I No 2 Agustus 2006.

Endraswara, Suwardi, Mistik Kejawen, Yogyakarta: Narasi, 2006.

Falsafah Hidup Jawa, Yogyakarta: Cakrawala, 2006.

Gazalba, Sidi, Pengantar Kebudayaan sebagai Ilmu, Jakarta: Pustaka Antara, 1993.

Geertz, Clifford, Abangan, Santri dan Priyayi dalam Masyarakat Jawa, Jakarta: Pustaka Jaya, 1989.

Gie, The Liang, Konsepsi Kearah Penertiban Filsafat, Yogyakarta: Karya Kencana, 1977.

Hanafi, Hasan, Agama, Kekerasan dan Islam Kontemporer, Yogyakarta: Jendela, 2001.

Hariwijaya, Tata Cara Penyelenggaraan Perkawinan Adat Jawa, Yogyakarta: Hanggar Kreator, 2004.

Herusatoto, Budiyono, Simbolisme dalam Budaya Jawa, Yogyakarta: Hanindita, 1997. 
Khadziq, Islam dan Budaya Lokal, Belajar Memahami Realitas Agama dalam Masyarakat, Yogyakarta: Teras, 2009.

Koentjaraningrat, Kebudayaan Jawa, Jakarta: PN Balai Pustaka, 2000.

Muhadjir, Noeng, Metodologi Penelitian Kualitatif, Yogyakarta: Rake Sarasin, 1996.

Mulder, Nields, Kepribadian Jawa dan Pembangunan Nasional, Yogyakarta: Gadjah Mada University Press, 1986.

Muti'ah, Anisatun, dkk., Penyerapan Nilai-nilai Budaya Lokal dalam Kehidupan Beragama di Cirebon dalam Harmonisasi Agama dan Budaya di Indonesia, Jakarta: Balitbang Agama, 2009.

Prabowo, Dhanu Priyo, Pengaruh Islam dalam Karya-karya R.Ng. Ranggawarsita, Yogyakarta; Narasi, 2003.

Pringgawidagda, Suwarna, Tata Upacara dan Wicara Pengantin Gaya Yogyakarta, Yogyakarta: Kanisius, 2006.

Purwadi, Tata Cara Pernikahan Pengantin Jawa, Yogyakarta: Media Abadi, 2004.

Rahman, Budhy Munawar, Islam Pluralis: Wacana Kesetaraan Kaum Beriman, Jakarta: Paramadina, 2001.

Razak, Nasruddin, Dienul Islam, Bandung: Al-Ma’arif, 1993.

Ricklefs, Sejarah Indonesia Modern, Yogyakarta: Gadjah Mada Press, 1995.

Roqib, Moh., Harmoni Budaya Jawa, Yogyakarta: Pustaka Pelajar, 2007.

Shidarta, Darji Darmono, Pokok-pokok Filsafat Hukum: Apa dan Bagaimana Filsafat Hukum Indonesia, Jakarta: Gramedia, 2006.

Sholikhin, M., Filsafat dan Metafisika dalam Islam, Yogyakarta: Narasi, 2008.

Simuh, Sufisme Jawa, Transformasi Tasawuf Islam ke Mistik Jawa, Yogyakarta: Yayasan Bentang Budaya, 1996.

Suratno, Siti Chamamah, "Agama dan Pluralitas Budaya Lokal: Dialektika Pemerkayaan Budaya Islam Nasional" dalam Zakiyuddin Baidhawy, Agama dan Pluralitas Budaya Lokal, Surakarta: Pusat Studi Budaya dan perubahan Sosial, Surakarta, 2002.

Susanto, Astri S., Pengantar Sosiologi dan Perubahan Sosial, Bandung: Bina Cipta, 1979.

Suseno, Frans Magnis, Etika Jawa, Jakarta: Gramedia, 2001.

Walisongo, Volume 21, Nomor 2, November 2013 
Tafsir, Ahmad, Filsafat Umum, Bandung: Remaja Rosda Karya, 2003.

Wardjoyo, Soesanto Poespo, Sekitar Manusia, Bunga Rampai tentang Filsafat Manusia, Jakarta: Gama Media, 1979. 